\title{
A new species of the Alvania pagodula group (Monterosato, I 890) from the Pliocene of Italy:A. agathae n. sp. (Gastropoda Rissoidae)
}

\author{
Agatino Reitano ${ }^{*}$, Massimo Cresti ${ }^{2} \&$ Davide Di Franco ${ }^{3,4}$ \\ ${ }^{1}$ Museo Civico di Storia Naturale, via degli Studi 9, 97013 Comiso, Ragusa, Italy \\ ${ }^{2}$ Via Argiano 8, 50026 San Casciano in Val di Pesa, Firenze, Italy \\ ${ }^{3}$ Department of Marine Zoology, Senckenberg Research Institute and Natural History Museum, Frankfurt, Germany \\ ${ }^{4}$ Institute of Ecology, Diversity and Evolution, Goethe University Frankfurt, Frankfurt, Germany \\ ${ }^{*}$ Corresponding author, e-mail: tinohawk@yahoo.it
}

\begin{abstract}
Alvania agathae n.sp. is described from the Pliocene of Italy. The new species is based on 17 fossil shells found in Pliocene layers of Sicily and Tuscany and belongs to the genus Alvania (Risso, 1826). Alvania agathae n.sp. is relatively close to A. spinosa (Monterosato, 1890), grouped within Alcidiella Cossmann, 1921, usually treated as a subgenus or synonym of Alvania. The description and the comparison with other Mediterranean similar fossil and living species are here reported. The possible phylogeny of the new, as well as related species included A. spinosa, is also discussed.
\end{abstract}

KEY WORDS Rissooidea; Alvania; Pliocene; new species; Buccheri; Orciano Pisano.

Received 14.11.2020; accepted 06.12.2020; published online 30.12.2020

\section{INTRODUCTION}

Rissoidae, with related genera, is one of the most diverse families of marine molluscs in the world. In particular, species of the genus Alvania (Risso, 1826) inhabit a large variety of different environments, from shallow to bathyal depth, in the Mediterranean Sea, the Atlantic, the Indo-Pacific and the temperate Australian coasts (Ponder 1985). Many authors contributed to the study of the family Rissoidae, describing many new taxa and expanding our knowledge on the taxonomy of this fascinating group.

In this paper, we describe Alvania agathae n.sp., a new remarkable species of the genus Alvania, based on fossil shells found in Pliocene layers of Sicily and Tuscany. This new species belongs to a group of species once grouped under the subgeneric name Alcidiella Cossmann, 1921, nowadays accepted as a synonym of Alvania, which is poorly studied and on which there are gaps in knowledge on the difference between species. Our findings allow us to discuss the presence of Alcidiella in the Mediterranean Plio-Pleistocene and to hypothesise a possible phylogeny between the fossil and living species closest to A. agathae $\mathrm{n}$. $\mathrm{sp}$.

\section{MATERIAL AND METHODS}

For the present paper, 30 kilos of sediments were collected from a sandy layer with Persistrombus coronatus (Defrance, 1827) cropping out in contrada Pirazzo, $500 \mathrm{~m}$ north of Masseria Pirazzo $\left(37^{\circ} 9^{\prime} 28.63^{\prime \prime} \mathrm{N} ; 14^{\circ} 52^{\prime} 25.03^{\prime \prime} \mathrm{E} ; 608 \mathrm{~m}\right.$ a.s.1.) along 
the east side of Monte Costerotte (851 m) at about 4 $\mathrm{km}$ from North-East of Buccheri, Siracusa, Italy. Further 50 kilos of sediments were collected from a sandy layer with Euspira helicina helicina (Brocchi, 1814) from excavation sites used for the construction of houses near the town of Orciano Pisano, Pisa, Italy.

Sediments were routinely washed, dried and sieved. Then, shell specimens were picked out from the $>10 \mathrm{~mm}$ fraction. The shell specimens were examined, measured and photographed under a stereomicroscope. In particular, the holotype and the Paratype 1 were also examined uncoated under a Zeiss LEO 1455 VP SEM microscope in Low Vacuum modality, to investigate its micromorphology. The repository number of the holotypes and the paratypes are given in the systematic descriptions.

ACRONYMS. Museo Civico di Storia Naturale di Comiso, Ragusa, Italy (MCSN); Massimo Cresti malacological collection, San Casciano in Val di Pesa, Firenze, Italy (MCC); Danilo Scuderi malacological collection, Belpasso, Italy (DSC), Alberto Villari malacological collection, Messina, Italy (AVC); Attilio Pagli malacological collection, Empoli, Italy (APC).

\section{RESULTS}

\section{Systematic Palaeontology}

Phylum MOLLUSCA Cuvier, 1797

Classis GASTROPODA Cuvier, 1795

Subclassis CAENOGASTROPODA Cox, 1960

Ordo LITTORINIMORPHA Golikov et Starobogatov, 1975

Superfamilia RISSOOIDEA Gray, 1847

Familia TROCHIDAE Rafinesque, 1815

Genus Alvania Risso, 1826

Type species: Alvania europea Risso $1826=$ Turbo cimex Linnaeus, 1758

Alvania agathae $\mathrm{n} . \mathrm{sp}$.

http://zoobank.org:act:44508215-7C04-49FCADA3-BBB675C69DEF

Type Locality. Pliocene of contrada Pirazzo, Buccheri, sandy layers with Persistrombus coronatus (Defrance, 1827), Siracusa, South-East Sicily, Italy (details under stratigraphy and paleoenvironment below).
EXAMINED MATERIAL. Holotype (Fig. 1), contrada Pirazzo, Buccheri, Siracusa, Sicily, Italy, (MSNC 4723). Paratypes and specimens same data of the holotype: paratype B and C (Figs. 2, 3) and paratype A (Fig. 4) (MSNC 4724), paratype D (Fig. 5 ) and $\mathrm{E}$ (MCC) from Orciano Pisano, paratypes F$\mathrm{R}$, and 8 specimens (MSNC 4725); 2 specimens (DSC), 1 specimen (AVC).

Description of the holotype. Shell conic, slender, slightly perforated, with a weak umbilical chink, sometimes absent and a pointed spire, slightly less high than the last whorl; height 3.2 $\mathrm{mm}$, width $2.03 \mathrm{~mm}, \mathrm{H} / \mathrm{W} 1.5$. Protoconch eroded (Fig. 1).

Just below the protoconch boundary, in the first tele-whorl, the median spiral keel could be detected. Teleoconch is constituted by 5 whorls, with weak sutures and a wide subsutural ramp. Sculpture is characterised by a marked spiral keel in the middle of the each whorl and axial ribs which form prominent spines at the intersection. The axial ribs and relative spines are thicker than the spiral keels, orthocline, 9 in number on the early tele-whorls, 11 on the body whorl. In the last whorl, which is about $1 / 3$ of the total length of the shell, a single spiral keel with 11 spines is present. From the upper insertion of the external lip to the base, there is a second keel below which the axial ribs are not visible. In fact, the base of the shell below the second keel is completely smooth. From the penultimate to the first tele-whorl this keel is visible as a faint uppersutural cord.

The aperture is ovate and slightly drop-shaped, with thin partially damaged peristome. The umbilicus is narrow.

VARIABILITY. Paratypes variation: shell height 3.1-3.5 mm, width 2.02-2.05, H/W 1.5-1.7 (Figs. 2, 3, 5). Protoconch (paratype A, Fig. 4) almost smooth, slender, conical, paucispiral, consisting of 1.5 regularly convex whorls with only thin and faint growth-lines; height $0.25 \mathrm{~mm}$, maximum diameter $0.27 \mathrm{~mm}$; nucleus inflated and inrolled; diameter $0.1 \mathrm{~mm}$; transition boundary from proto to teleoconch is marked (Figs. 8, 9, 12, 13).

Teleoconch with 5-5.5 whorls; axial ribs and relative spines 10-11 in number on the body whorl. In the last whorl 10-12 spines are present. A clear spiral micro-sculpture, detectable only at high magnifications, is present over all the shell surface but 

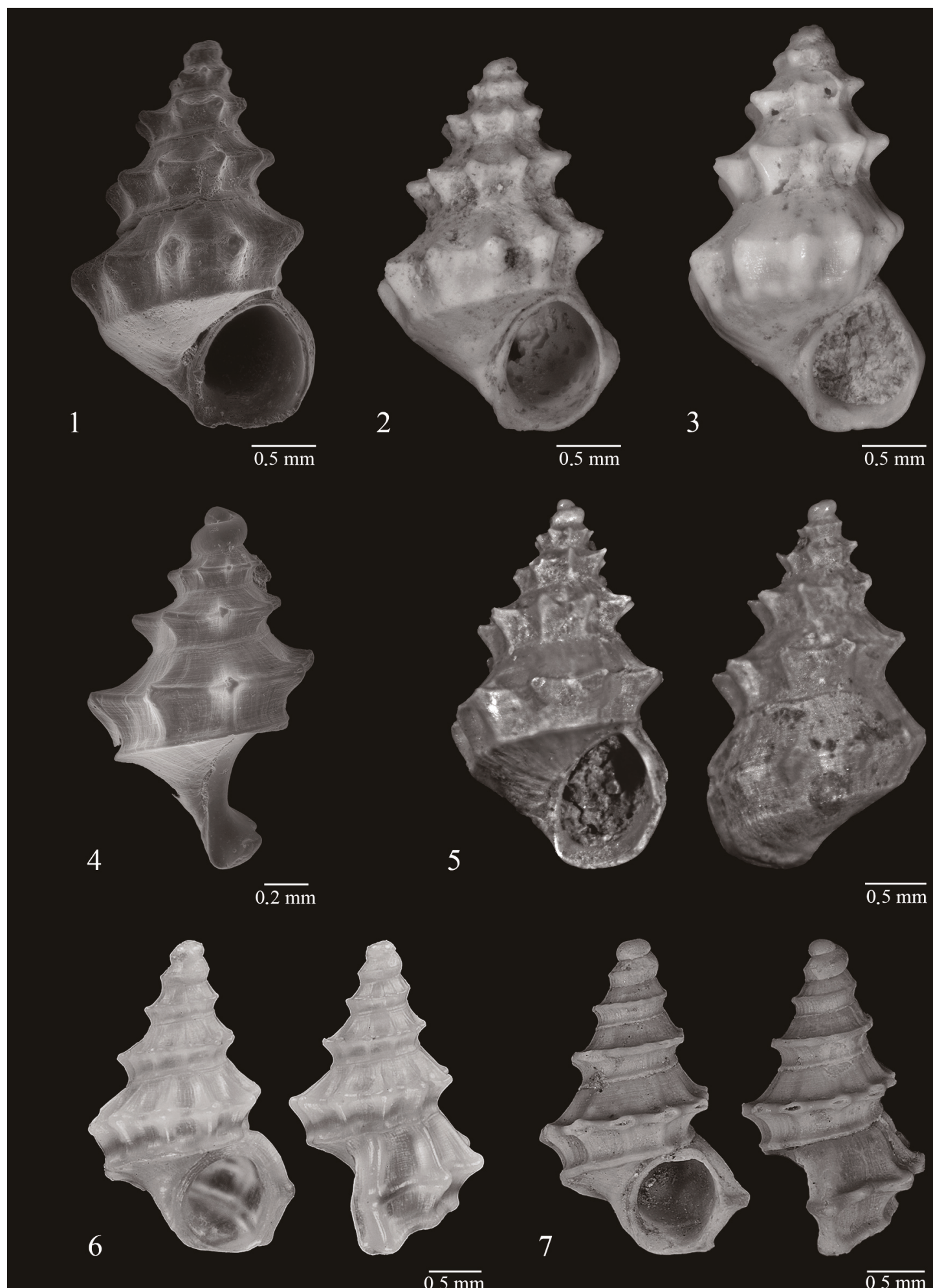

$\overline{0.5 \mathrm{~mm}}$

$\overline{0.5 \mathrm{~mm}}$

Figures 1-4. Alvania agathae n.sp., from type locality. Fig. 1: holotype, h: 3.3 mm. Fig. 2: paratype B, h: 3.1 mm. Fig. 3 : paratype C, h: $3.5 \mathrm{~mm}$. Fig. 4: paratype A, h: $1.63 \mathrm{~mm}$. Figure 5. Alvania agathae n.sp., paratype D, from Orciano Pisano, h: $2.95 \mathrm{~mm}$. Figure 6. Alvania tessellata Schwartz in Weinkauff, 1868, from Getares (Spain), beached in shell grit, h. $2.98 \mathrm{~mm}$ (APC). Figure 7. Alvania alboranensis Peñas et Rolán, 2006, from Motril (Spain), -110 m in shell grit, h. 2.78 mm (APC). 
better evident on the ab-sutural and ad-sutural zone of each whorl, where spiral lines are closer to each other (Fig. 14).

Etymology. The specific name is after the Agata Conti (Catania, Italy), mother of the first author (A.R.).

Stratigraphy and Paleoenvironment. Buccheri (Siracusa, Sicily, Italy). Sediments were collected in contrada Pirazzo in lenticular sandy and calcarenitic layers, located in the area of Buccheri. They were characterised by the presence of Persistrombus coronatus (Defrance, 1827) and by a rich malacofauna from pliocenic shallow marine environments (Philippi, 1844; De Gregorio, 1882; Alemagna, 1920; Glibert, 1960; Glibert \& Van de Poel, 1965; Grasso et al., 1979; Carbone et al, 1986; La Perna, 1999). Molluscan assemblages are characterized mainly by the Posidonia meadows (HP) and photophilic algae (AP) biocenosis (sensu Pérès \& Picard, 1964): Tricolia pullus (Linnè, 1758), Jujubinus spp., Clanculus spp., Persistrombus coronatus (Defrance, 1827); fine-grained well sorted sands biocenonsis (SFBC): Glycymeris spp., Spisula subtruncata (Da Costa, 1778), Neverita olla (De Serres, 1829), Chamelea gallina (Linnaeus, 1758); superficial muddy sands in sheltered areas biocenosis (SVMC): Loripes lacteus (sensu Poli, 1791), Bittium deshayesi Cerulli-Irelli,1912; coastal detritic biocenosis (DC): Tellina serrata Brocchi, 1814, Erato spp. and muddy detritic bottom biocenosis (DE): Timoclea ovata (Pennant, 1777), Plagiocardium papillosum (Poli, 1795), Bolma rugosa (Linnaeus, 1767), Calyptraea chinensis (Linnaeus, 1758).

Orciano Pisano (Pisa, Tuscany, Italy). The material from Orciano Pisano was sampled in grayish clay with Euspira helicina elicina (Brocchi, 1814), Ringicula buccinea (Brocchi, 1814), Pagodula echinata (Kiener, 1839), probably belonging to the "facies Piacenziana" (Brunetti et al, 2017 and references therein; Brunetti \& Cresti, 2018), characterized by shell assemblage from circalittoral and epibathial paleoenvironments.

REMARKS. Alvania agathae n. sp. belongs to the so-called $A$. pagodula group, including four different extant species Mediterranean species (WoRMS 2020): A. alboranensis Peñas et Rolán, 2006 (most probably a subfossil species), A. pagodula (Bucquoy, Dautzenberg et Dollfus, 1884), A. spinosa (Monterosato, 1890) and $A$. tessellata Schwartz in
Weinkauff, 1868. These were previously grouped within the subgeneric name Alcidiella (Van Aartsen, 1976). However, Ponder (1985) did not give any taxonomical significance to the latter, in spite of the common features shared between the four species (Van Aartsen, 1976, Palazzi, 1996). The Miocene fossil species $A$. munita Palazzi, 1996, included in Alcidiella by the author, shares some features with the $A$. pagodula group and partially with $A$. agathae n. sp., but is different on account of a greater number of spiral cords.

At the current state of knowledge, no other Tertiary fossil Alvania species are directly comparable with $A$. agathae n. sp.

Alvania spinosa is known as fossil record from Pleistocene layers of Gravitelli and Milazzo (Seguenza G., 1873-1874; Seguenza L., 1903; Greco \& Lima, 1974); we found some further specimens from the inferior Pleistocene (Sicilian stage) of Augusta (Di Geronimo et al., 2000). Seguenza L. (1903) did not provide any description or draw of Alcidia spinosa, ex A. angulata (Seguenza G., 1874, not 1876)= Alcidia spinosa (Monterosato, $1890)$ and for this reason, it is not possible to correctly address this species to any other known $\mathrm{Al}$ vania. Furthermore, Seguenza Luigi's collection (originally owned by his father Giuseppe) got lost and partially destroyed during the earthquake of 1908 (Bertolaso \& Palazzi, 2000). However, Monterosato (1890) synonymised "R. angulata (not Eichwald, 1830) Seguenza mss." as Alcidia spinosa; although the reason for such choice is unknown.

Tringali (2001), based on actual specimens collected in Mediterranean shores of Morocco, claims that $A$. spinosa (Monterosato, 1890) sensu Pallary (1902, 1920) is a morphotype of $A$. tessellata, considering the great variability shown by the latter species. Such assumption was recently accepted by Gofas et al. (2011), although it was not reported in WoRMS (2020). Alvania spinosa s.s. is characterized by a single median keel bearing spines, while A. tessellata presents a second less developed keel with spines, located halfway between the median region and the suture. However, Tringali's hypothesis was not based on the direct comparison between his samples and the holotype of $A$. spinos (as reported in his study, the author was not able to find it in Monterosato's collection housed in the zoological museum in Rome) or specimens from Thyrrenian Sea. Moreover, the figure (42: 23 C) of 


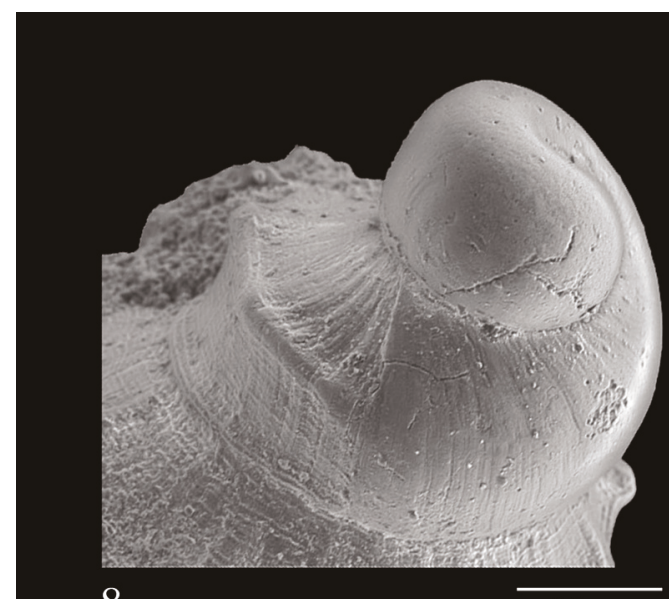

8

$0.1 \mathrm{~mm}$

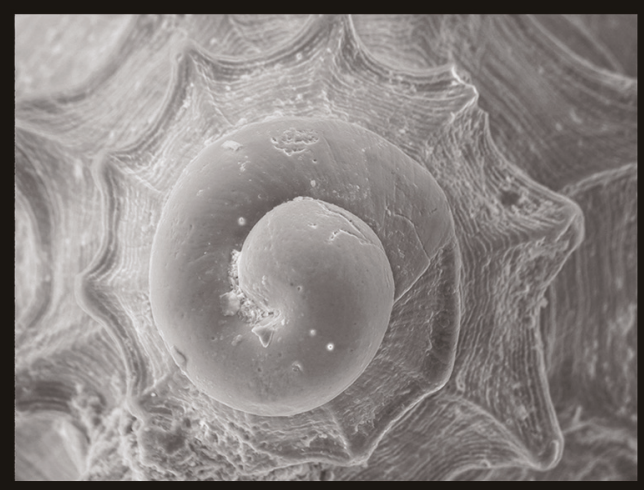

9

$0.1 \mathrm{~mm}$

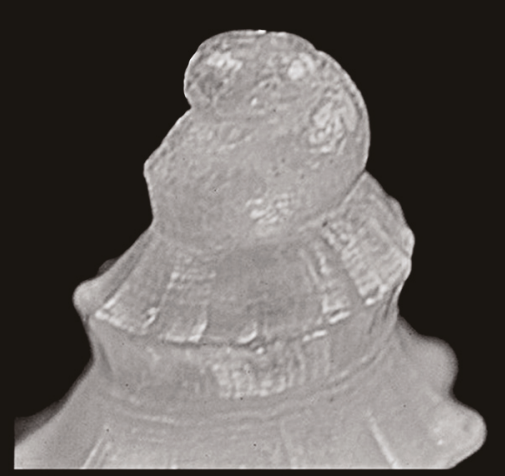

10

$\overline{0.2 \mathrm{~mm}} 11$

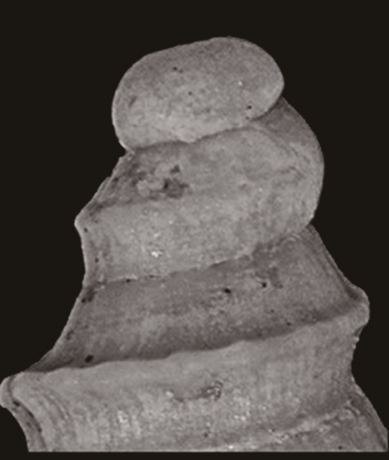

$\overline{0.2 \mathrm{~mm}}$

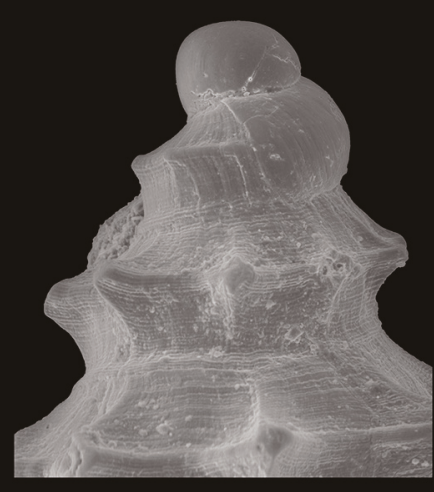

12

$\overline{0.1 \mathrm{~mm}}$

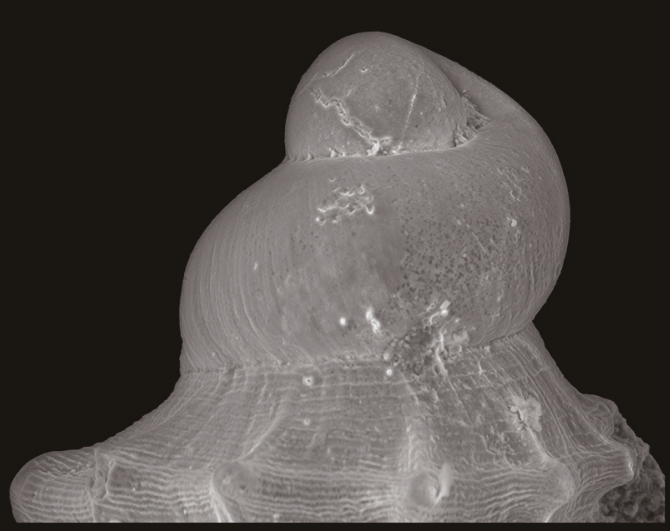

13
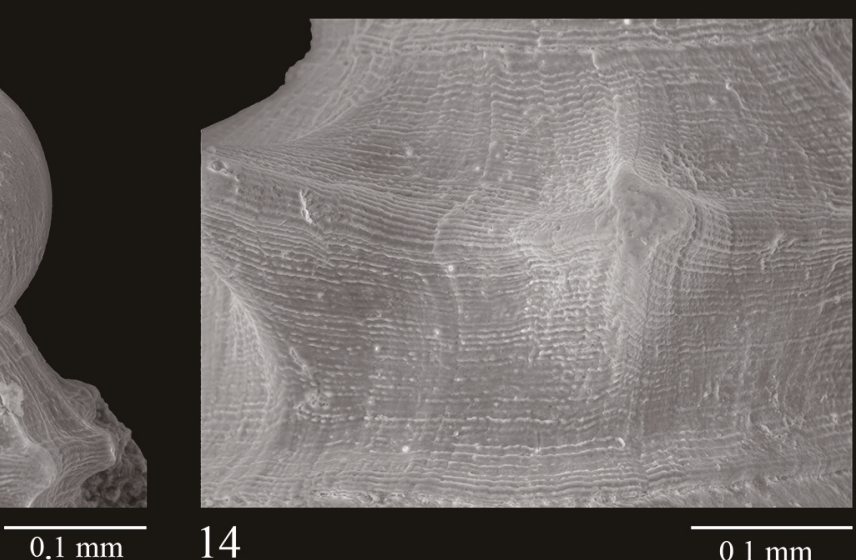

14

$0.1 \mathrm{~mm}$

Figures 8, 9, 12, 13. Alvania agathae n.sp, paratype A from type locality, details of apex. Figure 10. Alvania tessellata Schwartz in Weinkauff, 1868, from Getares, (Spain) beached: detail of apex (APC). Figure 11. Alvania alboranensis Peñas et Rolán, 2006, from Motril (Spain) -110 m in shell grit: detail of apex (APC). Figure 14. micro-sculpture of Alvania agathae n.sp, paratype A. 
the specimen of $A$. spinosa (Institut Royal des Sciences Naturelles de Belgique, ex Monterosato) reported in Ponder (1985), does not match with the original description of $A$. spinosa and rather looks like a specimen of $A$. tessellata s.s.

According to the recent literature (GiannuzziSavelli et al., 1996; Cossignani, 2011; Scaperrotta et al., 2012), A. spinosa is distributed only in the Alboràn Sea.

Probably, specimens referable to $A$. spinosa s.s. belong to the suprapleistocenic thanatocenoses from the deep sea in the low Tyrrhenian Sea.

In light of this, A. agathae n. sp. will be compared mainly with $A$. tessellata and its morphotype A. spinosa sensu auctores.

Alvania agathae n.sp. differs from A. spinosa sensu auctores in having a smoother apex, a bigger size, a different height/last whorl ratio, a wider and completely smooth base, a simple and thin peristome lacking of spines, and a more prominent teleoconch with pointed spines.

Alvania agathae n.sp. differs from $A$. tessellata s.s. in having a single median keel (Fig. 6); the species is more similar to A. alboranensis (Fig. 7), which also have a hint of axial sculpture. However, A. agathae n. sp. differs from $A$. alboranensis in its keel, located in the last whorl starting from the superior margin of the peristome; furthermore, the keel in A. agathae n. sp. is smooth and sharper. Ultimately, A. agathae n.sp. has a more or less convex basis instead of canaliculated, being this latter character characteristic of $A$. alboranensis s.s.

\section{ACKNOWLEDGEMENTS}

We thank Leonardo Reitano, son of A.R., Danilo Scuderi (Belpasso, Italy), Fabio Liberto (Cefalù, Italy), Salvo Giglio (Cefalù, Italy), Aldo Brancato (Siracusa, Italy), Stefano Palazzi (Milo, Catania, Italy) and Francesco Sciuto (Viagrande, Catania, Italy), for the valid contribute on the field and for helping with the sediment sampling. Thanks are due to: Paolo Albano, Department of Paleontology, University of Vienna (Austria), for the support during photography and image processing; Andrea Nappo (Cagliari, Italy) and Attilio Pagli (Empoli, Italy) for providing us with photos of some shells shown here. We are also grateful to Danilo Scuderi for the precious contribution dur- ing the drafting of the text and critical revision of the manuscript.

\section{REFERENCES}

Alemagna C., 1920. Osservazioni geologiche nei dintorni di Buccheri, in provincia di Siracusa. Atti Acc. Gioenia Sc. Nat. Catania, s. 5, 12: 12pp.

Bertolaso L. \& Palazzi S., 2000. Note sulla raccolta Seguenza di molluschi plio-pleistocenici della Provincia di Messina conservata presso il Museo di Geologia e Paleontologia dell'Università di Firenze. Bollettino Malacologico, 35: 3-44.

Brunetti M.M., Cresti M. \& Forli M., 2017. Un nuovo Rissoidae Gray, 1847 per il Pliocene italiano: Rissoa sarae n. sp. Bollettino Malacologico, 53: 75-78.

Brunetti M.M. \& Cresti M., 2018. I Fossili di Orciano Pisano. Atlante Iconografico. Edizioni Danaus, Palermo, $232 \mathrm{pp}$.

Carbone S., Grasso M. \& Lentini F., 1986. Carta geologica del settore nord-orientale ibleo (Sicilia SE), scala 1:50.000. S.El.Ca. Firenze.

Cossignani T. \& Ardovini, 2011. Malacologia Mediterranea, Atlante delle conchiglie del Mediterraneo: 536pp. L'informatore Piceno, Ancona.

De Gregorio A., 1882. Su talune specie e forme nuove degli strati terziari di Malta e del Sud Est di Sicilia. Il Naturalista siciliano, 1: 217-223.

Di Geronimo I., 1991. Mollusca: specie nuove plio-quaternarie di G. Seguenza (1858-1881). Atti Accademia peloritana dei Pericolanti, 67, suppl. 1, parte 1: 137254.

Di Geronimo I., Di Geronimo R., La Perna R., Rosso A. \& Sanfilippo R., 2000. Cooling evidence from Pleistocene shelf assemblages in SE Sicily. In: Hart M. B. (Ed.), Climates: Past and Present. Geological Society, London, Speciale Pubblications, 181: 113-120.

Giannuzzi-Savelli R., Pusateri F., Palmeri A. \& Ebreo C., 1996. Atlante delle Conchiglie Marine del Mediterraneo. Atlas of the Mediterranean Sea Shells. Vol. II. Edizioni de "La Conchiglia' Roma.

Glibert M., 1960. Les Conacea fossiles du Cénozoïque étranger. Institute Royal Sciences Naturelles Belgique, Mémories, $2^{\wedge}$ ser., fasc. 64, 132 pp. Bruxelles.

Glibert M. \& Van de Poel L., 1965. Les Bivalvia fossiles du Cénozoïque étranger. Inst. Royal Sci. Nat. Belgique, Mémories, $2^{\wedge}$ ser., fasc. 78, 106 pp. Bruxelles.

Gofas S., Moreno D. \& Salas C., 2011. Moluscos marinos de Andalucía.Volumen I, pp. I-XVI and 1-342. Málaga: Servicio de Publicaciones e Intercambio Científico, Universidad de Málaga.

Grasso M., Lentini F., Lombardo G. \& Scamarda G., 1979. Distribuzione delle facies cretaceo-mioceniche 
lungo l'allineamento Augusta-M. Lauro (Sicilia sudorientale). Italian Journal of Geosciences, 98: 175188.

Greco A. \& Lima N., 1974. Repertorio dei molluschi marini plio-pleistocenici della Sicilia. Parte I. Lavori dell'Istituto di Geologia della Università di Palermo, n. 14: 140 pp.

La Perna R., 1999. Granulina elliptica n. sp. and comments on the Mediterranean Pliocene species of Granulina (Gastropoda, Marginellidae). Bollettino Malacologico, 35: 53-55.

Monterosato T., 1890. Conchiglie della profondità del mare di Palermo. Il Naturalista siciliano, 9: 140-151, 157-166, 181-191.

Pallary P., 1902. Liste des mollusques testaces de la Baie de Tanger. Journal of Conchology, 50: 1-39.

Pallary P., 1920. Exploration scientifique du Maroc organisée par la Société de Géographie de Paris et continuée par la Société des Sciences Naturelles du Maroc. Deuxième fascicule. Malacologie (1912). Larose, Rabat et Paris, 108 pp.

Peñas A., Rolán E., Luque Á.A., Templado J., Moreno D., Rubio F., Salas C., Sierra A. \& Gofas S., 2006. Moluscos marinos de la isla de Alborán. Iberus, 24: 23-151.

Pérès J.M. \& Picard J., 1964. Nouveau manuel de bionomie benthique de la mer Méditerranée. Recueil des Travaux de la Station Marine d'Endoume, Faculté des Sciences de Marseille, 31: 1-137.

Philippi R.A., 1844. Enumeratio Molluscorum Siciliae cum viventium tum in tellure tertiaria fossilium, quae in itinere suo observavit. Volumen secundum continens addenda et emendanda, nec non comparationemfaunae recentis Siciliae cum faunis aliarum terrarumet com fauna periodi tertiariae. Eduard Anton, Halle[Halis Saxorum]. Iv+303: 13-28.

Ponder W., 1985. A review of the genera of the Rissoidae (Mollusca, Mesogastropoda, Rissoacea). Records of the Australian Museum Supplement 4, 1-221.

Scaperrotta M., Bartolini S. \& Bogi C., 2012. Accrescimenti - Stadi di accrescimento dei Molluschi marini del Mediterraneo - Stages of growth of marine molluscs of the Mediterranean Sea, Vol. 4, 184 pp., L'Informatore Piceno, Ancona.

Seguenza G., 1873-1874. Studi stratigrafici sulla formazione pliocenica dell'Italia meridionale. Bullettino del R. Comitato Geologico d'Italia, 207 pp., 2 tav.

Seguenza L., 1903. Rissoidi Neogenici della provincia di Messina. Palaeontografia italica, 9: 35-60, pl. 11.

Van Aartsen J.J., 1976. European marine Mollusca: notes on less well-known species. 1. Alvania (Alcidiella) spinosa Monterosato, 1890. Basteria 40: 127-132. 
